\title{
Sulfide-induced release of phosphate from sediments of coastal lagoons and the possible relation to the disappearance of Ruppia sp.
}

\author{
S. K. Heijs ${ }^{1,2}$, R. Azzoni ${ }^{3}$, G. Giordani ${ }^{3}$, H. M. Jonkers ${ }^{1}$, D. Nizzoli ${ }^{3}$, \\ P. Viaroli ${ }^{3}$, H. van Gemerden ${ }^{1, *}$ \\ ${ }^{1}$ Microbial Ecology, Centre for Ecological and Evolutionary Studies (CEES), University of Groningen, PO Box 14, \\ 9750 AA Haren, The Netherlands \\ ${ }^{2}$ Netherlands Institute of Ecology, Centre of Estuarine and Coastal Ecology, PO Box 140, 4400 AC Yerseke, The Netherlands \\ ${ }^{3}$ Department of Environmental Sciences, University of Parma, Viale delle Scienze 33/a, 43100 Parma, Italy
}

\begin{abstract}
The production and consumption of sulfide and its influence on phosphorous cycling were studied in a hypertrophic coastal lagoon (Valle Smarlacca, Italy). Oxygen measurements revealed that the water phase was supersaturated except for the layer directly overlying the sediment. This layer was devoid of oxygen and contained sulfide at all times. Maximal rates of sulfide production, calculated from in situ profiles, were observed in the 0 to $2 \mathrm{~cm}$ sediment layer and the $1 \mathrm{~cm}$ water layer directly above. Sediment iron data suggested a moderate chemical buffering capacity towards free sulfide; however, the in situ buffering capacity was fully exploited. Stirring increased the chemical buffer, indicating that, in situ, part of the iron did not contribute to the chemical buffer. The potential rate of biological sulfide oxidation, estimated in sediment slurries amended with oxygen, was high; however, the actual rate was low due to a shortage of oxygen in the sediments and the overlying water. Evidence was obtained for enhanced release of phosphate caused by free sulfide. Under simulated natural conditions the release of phosphate exceeded the initial concentration of Febound phosphate by an order of magnitude, indicating a significant contribution of non-iron-bound phosphate. The observations in Valle Smarlacca were used to shed light on the virtually complete disappearance of Ruppia sp. from other lagoons of the Valli di Comacchio (Northern Italy).
\end{abstract}

KEY WORDS: Eutrophication $\cdot$ Phosphate mobilization $\cdot$ Sulfide production $\cdot$ Ruppia $\cdot$ Coastal lagoons

\section{INTRODUCTION}

Over the past decade coastal lagoons have been studied extensively with respect to eutrophication processes. Many of these systems have large catchment areas, which thus receive considerable quantities of phosphorus and nitrogen, and consequently contain high biomasses of primary producers. As a result anoxia is common, particularly when light intensities are low.

In shallow marine environments organic matter mineralization coupled to sulfate reduction is a prominent

*Corresponding author. E-mail: h.van.gemerden@biol.rug.nl process (Jørgensen 1982). The ample presence of organic matter combined with the absence of oxygen will stimulate the proliferation of obligately anaerobic sulfate-reducing bacteria; the resulting sulfide is highly toxic and its presence in an unbound form may have far-reaching consequences for ecosystem functioning.

Water purification has been introduced in many European countries and phosphate is no longer added to most detergents. As a result, eutrophication in nearshore waters has decreased significantly; however, sediments harbor large amounts of bound P. Once released as phosphate, they act as the P source for pri- 
mary producers and other (micro)organisms in the water column. The relevant inorganic forms of $\mathrm{P}$ in the sediment are ferric iron-bound (Fe-bound) and calcium-bound (Ca-bound) phosphates (Boström et al. 1988). During anoxia, phosphate is released from the Fe-bound pool (Stal et al. 1996) and a positive relation with elevated rates of sulfate reduction has been demonstrated (Smolders \& Roelofs 1993, Giordani et al. 1996, Roden \& Edmonds 1997). It is generally assumed that such conditions do not affect Ca-bound phosphate (Moore \& Reddy 1994, Golterman 1995, 1997).

The floral composition in the Valli di Comacchio (Northern Italy), an ecologically and economically important coastal lagoonal ecosystem, has changed dramatically over the past decades. Whereas the lagoons in the early 1970s were dominated by large beds of Ruppia sp., recent observations show that Ruppia has virtually disappeared (Piccoli 1998), despite the fact that nutrient concentrations have decreased (Sorokin et al. 1996a, Dallocchio et al. 1998).

A possible explanation for the declining Ruppia population could be its sensitivity towards sulfide. Many rooted phanerogams significantly contribute to the aerobic oxidation of sulfide by virtue of their ability to enrich a small sediment area directly around the roots with oxygen, a phenomenon known as radial oxygen loss (ROL) (Caffrey \& Kemp 1991, Pedersen et al. 1998). Ruppia roots exposed to sulfide could lose their functionality in this respect, which would result in enhanced sulfide concentrations, in particular in the direct surroundings of the roots. The increased sulfide concentration in the pore water could effectuate an even more enhanced phosphate eutrophication. Eventually this cascade of reactions could have resulted in the complete elimination of Ruppia from the lagoon. To validate this hypothesis, data were collected in Valle Smarlacca (Italy). The present situation in this lagoon may reflect a situation encountered in the past in other lagoons of the Valli di Comacchio.

This paper describes the results of a combined field and laboratory study in which the effect of production and consumption of sulfide on phosphorous cycling was investigated. The possible relation with the survival of Ruppia in coastal lagoons is discussed.

\section{MATERIALS AND METHODS}

Site description. The Valli di Comacchio lagoonal system $\left(44^{\circ} 20^{\prime} \mathrm{N}, 12^{\circ} 10^{\prime} \mathrm{E}\right)$, a characteristic brackish water environment which has been used for aquaculture for centuries, covers a total area of $110 \mathrm{~km}^{2}$ and consists of 3 main lagoons
(Valle Lido di Magnavacca, Valle Fossa di Porto and Valle Campo) and a number of smaller lagoons (Fig. 1), all with water depths of 50 to $150 \mathrm{~cm}$. The water level is regulated by channels which are directly or indirectly connected to the Adriatic Sea to the east or to the Reno River to the south. The surficial sediments are mainly silt, rich in organic detritus with a low percentage of sand, while the deeper sediment layers are mostly silty-clay. The lagoons of the Valli di Comacchio have been classified by Sorokin et al. (1996b) as hypertrophic and characterized by blooms of cyanobacteria; however, an annual survey has shown that the cyanobacterium Synechococcus and the small green alga Nannochloropsis were present in equal numbers in the January to April period, whereas the green alga dominated $(\sim 90 \%)$ over the remainder of the year (Andreoli et al. 1998).

The Valle Smarlacca (total surface area $2 \mathrm{~km}^{2}$ ) is located in the south-east corner of the Valle Lido di Magnavacca and consists of several small fish ponds and 1 larger basin. The lagoon, in part still colonized by Ruppia cirrhosa, is completely separated from the other lagoons of the Valli di Comacchio and receives water directly from the Reno River. The larger basin of the lagoon was sampled in September 1998.

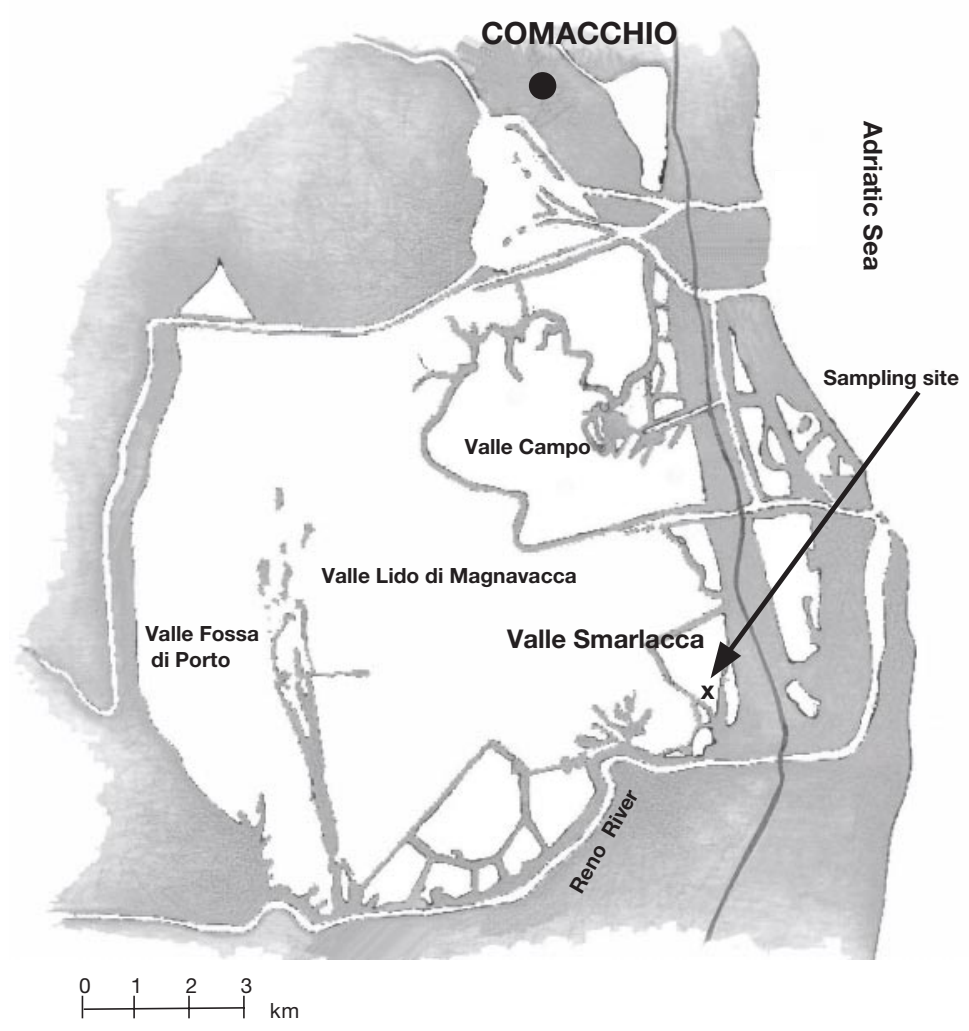

Fig. 1. Overview of the Valli di Comacchio, Italy $\left(44^{\circ} 20^{\prime} \mathrm{N}\right.$, $\left.12^{\circ} 10^{\prime} \mathrm{E}\right)$ and the location of the sampling site in Valle Smarlacca 
Sampling and in situ profiles of oxygen and sulfide. Sediment samples were collected with acrylic cores $(\varnothing 5 \mathrm{~cm})$, butyl-rubber stoppered at the bottom end, and, within $1 \mathrm{~h}$, sliced in 3 consecutive layers $(0-2,2-5$ and $5-10 \mathrm{~cm}$ ).

Water samples were collected by means of 3 tubes fixed to a pole at 50,25 and $1 \mathrm{~cm}$ above the sediment surface. Concentrations of total sulfide (free plus acid volatile) and oxygen were measured using the methylene blue method (Cline 1969; detection limit $1 \mu \mathrm{M}$ ) and the Winkler method (APHA 1975, detection limit 2 to $4 \mu \mathrm{M})$, respectively.

In situ vertical profiles of oxygen and free sulfide $\left(\mathrm{S}^{2-}\right)$ in the sediment and the overlaying $1 \mathrm{~cm}$ water layer were assessed hourly over a diel cycle using a computer-controlled submersible bottom profiler as described by Schaub \& Van Gemerden (1996), equipped with needle electrodes of $20 \mathrm{~cm}$ length (Microscale Measurements, The Netherlands). Calibration was performed under non-stirred conditions. Sulfide data were $\mathrm{pH}$ corrected to yield total free sulfide $\left(\sum \mathrm{H}_{2} \mathrm{~S}, \mathrm{HS}^{-}\right.$, $\mathrm{H}_{2} \mathrm{~S}$ ) based on readings obtained at $0.5 \mathrm{~cm}$ depth intervals. The detection limit for oxygen and free sulfide is 2 to 4 and $5 \mu \mathrm{M}$, respectively.

Iron and acid-volatile sulfide. Iron pools were measured by 2 parallel extractions using $1 \mathrm{~g}$ of wet sediment. 'Labile iron' (Lovley \& Phillips 1987) was extracted with $0.5 \mathrm{M} \mathrm{HCl}_{\text {; }}$ in this pool ferric iron consists mainly of amorphous Fe(III)-oxyhydroxides, while ferrous iron mainly consists of acid-volatile sulfides (AVS). 'Chemically reactive iron' (Canfield 1989) was extracted with $6 \mathrm{M} \mathrm{HCl}_{\text {; }}$ this pool comprises all iron with the exception of pyrite and some stable complexes and minerals in which iron can be in the ferrous or the ferric state. Chemically reactive iron includes labile iron. Crystalline reactive iron concentrations were obtained by subtraction of the $0.5 \mathrm{M} \mathrm{HCl}$ extraction data from the $6 \mathrm{M} \mathrm{HCl}$ extraction data. Immediately after slicing, the $1 \mathrm{~g}$ sediment samples were suspended in $20 \mathrm{ml}$ of acid ( 0.5 or $6 \mathrm{M} \mathrm{HCl}$ ) and shaken for $12 \mathrm{~h}$. Iron pools in $6 \mathrm{M} \mathrm{HCl}$-treated slurry samples were determined after $0.5 \mathrm{ml}$ slurry was added to $10 \mathrm{ml}$ $0.5 \mathrm{M} \mathrm{HCl}$.

Ferrous iron was measured using the ferrozine method (Lovley \& Phillips 1987). Ferric iron was determined by subtraction after reduction with $0.3 \mathrm{M}$ hydroxylamine.

In slurry samples collected from the Biological Oxygen and Sulfide Monitor (BOSM) (Heijs et al. 1999), the pool of labile ferrous and ferric iron was determined in the filtered and acidified supernatant $(0.2 \mathrm{ml} 0.5 \mathrm{M}$ $\mathrm{HCl}$ per $2.5 \mathrm{ml}$ ) of centrifuged slurries. These analyses were carried out at the beginning of the experiment prior to the addition of oxygen and/or sulfide and at the end of the experiment.
AVS, representing free sulfide $\left(\sum \mathrm{H}_{2} \mathrm{~S}, \mathrm{HS}^{-}, \mathrm{S}^{2-}\right)$ and ferrous sulfide $(\mathrm{FeS})$, was determined by acidifying known sediment volumes under anoxic conditions (Heijs et al. 1999).

Phosphorus. A number of distinct phosphorus pools were measured in the water phase, in the sediment and in samples from the BOSM set-up, using the colorimetric molybdate method of either Valderrama (1981) (more sensitive, but lower upper limit) or Murphy \& Riley (1962) (less sensitive, but higher upper limit). Interferences due to the presence of sulfide were avoided by adding $0.4 \mathrm{ml}$ of $0.5 \mathrm{M} \mathrm{HCl}$ to $5 \mathrm{ml}$ sample $24 \mathrm{~h}$ before the assay was performed.

In the water phase, dissolved $\mathrm{PO}_{4}$, total particulate $\mathrm{P}$ and total dissolved $\mathrm{P}$ were determined. The conversion of total $\mathrm{P}$ to $\mathrm{PO}_{4}$ was performed according to Valderrama (1981).

From the sediment, pore water samples were collected under anoxic conditions as described by Reeburgh (1967), whereafter dissolved $\mathrm{PO}_{4}$ was determined. In sliced sediment samples (triplicate cores) 4 phosphorus pools were determined by sequential extractions using $1 \mathrm{~g}$ of wet sediment: (1) exchangeable $\mathrm{PO}_{4}$, (2) Fe-bound $\mathrm{PO}_{4}$, (3) authigenic Ca-bound $\mathrm{PO}_{4}$, and (4) detrital Ca-bound $\mathrm{PO}_{4}$ (Hieltjes \& Lijklema 1980, Ruttemberg 1992, Barbanti et al. 1994). Exchangeable $\mathrm{PO}_{4}$ was measured by 2 anoxic extractions (2 $\mathrm{h}$ each) with $1 \mathrm{M} \mathrm{MgCl}_{2}$ buffered to $\mathrm{pH} 7.5$, whereafter the Fe-bound $\mathrm{PO}_{4}$ was extracted with $0.1 \mathrm{M}$ $\mathrm{NaOH}$ for $18 \mathrm{~h}$ under oxic conditions. The Ca-bound $\mathrm{PO}_{4}$ was separated into authigenic Ca- $\mathrm{PO}_{4}$ and detrital Ca- $\mathrm{PO}_{4}$ according to Ruttemberg (1992). Authigenic $\mathrm{Ca}-\mathrm{PO}_{4}$ was measured after $6 \mathrm{~h}$ extraction with $1 \mathrm{M}$ $\mathrm{Na}$-acetate buffered to $\mathrm{pH} 4$, whereas detrital $\mathrm{Ca}-\mathrm{PO}_{4}$ was measured after $1 \mathrm{~h}$ extraction with $0.5 \mathrm{M} \mathrm{HCl}$. After the $\mathrm{NaOH}$, acetate and $\mathrm{HCl}$ extractions, the sediment was rinsed with $1 \mathrm{M} \mathrm{MgCl}_{2}$ to extract $\mathrm{PO}_{4}$ readsorbed onto sediment particles. Dissolved $\mathrm{PO}_{4}$ in the extracts was measured in the supernatant as described above. In addition, total $\mathrm{P}$ was extracted with $37 \% \mathrm{HCl}$ from $0.1 \mathrm{~g}$ of ashed sediment and determined spectrophotometrically according to Aspila et al. (1976). Organic P was estimated as the difference between total $\mathrm{P}$ and the sum of all inorganic $\mathrm{P}$ pools.

In slurry samples collected from the BOSM, dissolved $\mathrm{PO}_{4}$ was determined in the filtered and acidified supernatant $(0.2 \mathrm{ml} 0.5 \mathrm{M} \mathrm{HCl}$ per $2.5 \mathrm{ml})$ of centrifuged slurries according to Murphy \& Riley (1962). These analyses were carried out prior to the addition of sulfide and at the end of the experiment.

Chlorophyll $a$ and gross oxygen production rates in the water column. Chlorophyll a ( $\mathrm{chl} a$ ) concentrations were determined by filtration of $100 \mathrm{ml}$ of water on a Whatman GF/F filter, followed by acetone extraction of the material retained on the filter (APHA 1975). 
Gross oxygen production rates of phytoplankton in the water column were determined as the difference between production and consumption of oxygen in transparent and dark glass bottles. Eight glass bottles of 1.21 (4 light, 4 dark), filled with water from the sampling site, were incubated in sunlight at $570 \mu \mathrm{E} \mathrm{m}^{-2} \mathrm{~s}^{-1}$ and $24.5^{\circ} \mathrm{C}$, thus mimicking the in situ conditions.

The oxygen concentration in each bottle was determined at the start of the experiment and after 0.5 and $1.5 \mathrm{~h}$ using the Winkler method.

Potential and actual chemical buffering capacity towards free sulfide. The potential chemical buffering capacity towards free sulfide was calculated from the labile ferrous and ferric iron pool according to Heijs et al. 1999. The measured buffering capacity was estimated by adding sulfide to sediment slurries until free sulfide became detectable (Heijs et al. 1999); compared to the in situ situation, this may reflect an overestimation due to the stirring of the BOSM contents. When free sulfide was present in the sediment, the in situ buffering capacity was assumed to be fully exploited.

Biological and chemical sulfide oxidation. In the BOSM set-up, changes in the concentrations of oxygen and sulfide can be monitored at time intervals ranging from 0.6 to $60 \mathrm{~s}$ using a custom-made computer program (Electronic Workshop, Biology Department, University of Groningen, The Netherlands). Using untreated and steamed slurries (15 min in steaming autoclave, resulting in a $99.9 \%$ loss of viable cells), this allows the determination of the potential total rate and the potential chemical rate of oxygen consumption (no sulfide limitation), as well as the potential total rate and the potential chemical rate of sulfide removal (no oxygen limitation). Potential biological rates were calculated by subtraction of potential chemical rates from potential total rates. A typical example of the results of a BOSM experiment is shown in Fig. 2 (details in legend).

Changes in the concentration of sulfide do not provide information on the nature of the products being formed, nor do changes in the concentrations of oxy- gen. However, the ratio between the rate of sulfide removal and the rate of oxygen consumption can be used to estimate the oxidation state of the sulfur compound formed: a complete oxidation of sulfide to sulfate results in a molar sulfide/oxygen ratio of 0.5 (Eq. 1), whereas incomplete oxidation of sulfide to sulfur yields a sulfide/oxygen ratio of 2 (Eq. 2)

$$
\begin{gathered}
\mathrm{HS}^{-}+2 \mathrm{O}_{2} \Rightarrow \mathrm{SO}_{4}{ }^{2-}+\mathrm{H}^{+} \\
2 \mathrm{HS}^{-}+\mathrm{O}_{2}+2 \mathrm{H}^{+} \Rightarrow 2 \mathrm{~S}^{0}+2 \mathrm{H}_{2} \mathrm{O}
\end{gathered}
$$

Slurries to be amended with oxygen were aerated for $10 \mathrm{~min}\left(187 \mathrm{ml} \mathrm{min}^{-1}\right)$. Sulfide was added as a HClneutralized, carbonate-buffered $(167 \mathrm{mM})$ solution of sodium sulfide (66 mM).

\section{RESULTS \\ Iron and phosphate}

The total reactive iron concentration, averaged over the top $10 \mathrm{~cm}$ of the sediment, was $121 \mu \mathrm{mol} \mathrm{cm} \mathrm{cm}^{-3}$, of which $74 \%$ was present as ferrous iron. Between the 3 layers examined $(0-2,2-5,5-10 \mathrm{~cm})$ differences were marginal with respect to the $\mathrm{Fe}^{2+} / \mathrm{Fe}^{3+}$ ratio; however, both ferrous and ferric iron concentrations increased with depth (Table 1). Labile ferrous iron was the dominant form in the top of the sediment, whereas in the deeper layers iron was for a large part crystalline. The concentration of labile ferrous iron bound in AVS virtually did not change with depth. At all depth horizons, less than $3 \%$ of total iron was present as labile ferric iron (Table 1). Total $\mathrm{P}$, both particulate and dissolved, showed no differences at 50 and $25 \mathrm{~cm}$ above the sediment surface, which indicates that the upper water column was well mixed. Closer to the bottom, particulate $\mathrm{P}$ was somewhat higher compared to the remaining water column, whereas dissolved $\mathrm{P}$ was lower; however, the differences were small. Dissolved $\mathrm{PO}_{4}$ concentrations were below the limit of detection $(0.1 \mu \mathrm{M})$, both in the water column and close to the surface of the sediment (Table 2).

Table 1. Iron speciation in the sediment of Valle Smarlacca (Valli di Comacchio, Italy) in September 1998. Average of triplicate

\begin{tabular}{|c|c|c|c|c|c|c|}
\hline \multirow{3}{*}{$\begin{array}{l}\text { Depth layer } \\
(\mathrm{cm})\end{array}$} & \multicolumn{3}{|c|}{- Ferrous iron $\left(\mu \mathrm{mol} \mathrm{cm}{ }^{-3}\right)-$} & \multicolumn{2}{|c|}{ Ferric iron $\left(\mu \mathrm{mol} \mathrm{cm} \mathrm{cm}^{-3}\right)$} & \multirow{3}{*}{$\begin{array}{c}\text { Ratio } \\
\mathrm{Fe}^{2+} / \mathrm{Fe}^{3+}\end{array}$} \\
\hline & & le & Crystalline $^{\mathrm{c}}$ & Labile $^{a}$ & Crystalline $^{\mathrm{c}}$ & \\
\hline & Total $^{\mathrm{a}}$ & $\mathrm{FeS}^{\mathrm{b}}$ & & & & \\
\hline $0-2$ & $32.3(10.1)$ & $16.9(1.3)$ & $16.8(14.7)$ & $0.8(0.9)$ & $14.1(4.3)$ & 3.3 \\
\hline $2-5$ & $42.3(2.8)$ & $19.0(6.5)$ & $26.1(12.4)$ & $2.6(2.5)$ & $20.8(9.7)$ & 2.9 \\
\hline $5-10$ & $55.5(4.9)$ & $14.1(1.6)$ & $60.8(70.6)$ & $0.0(2.2)$ & $45.7(8.5)$ & 2.7 \\
\hline
\end{tabular}
samples with standard deviations in brackets are given 

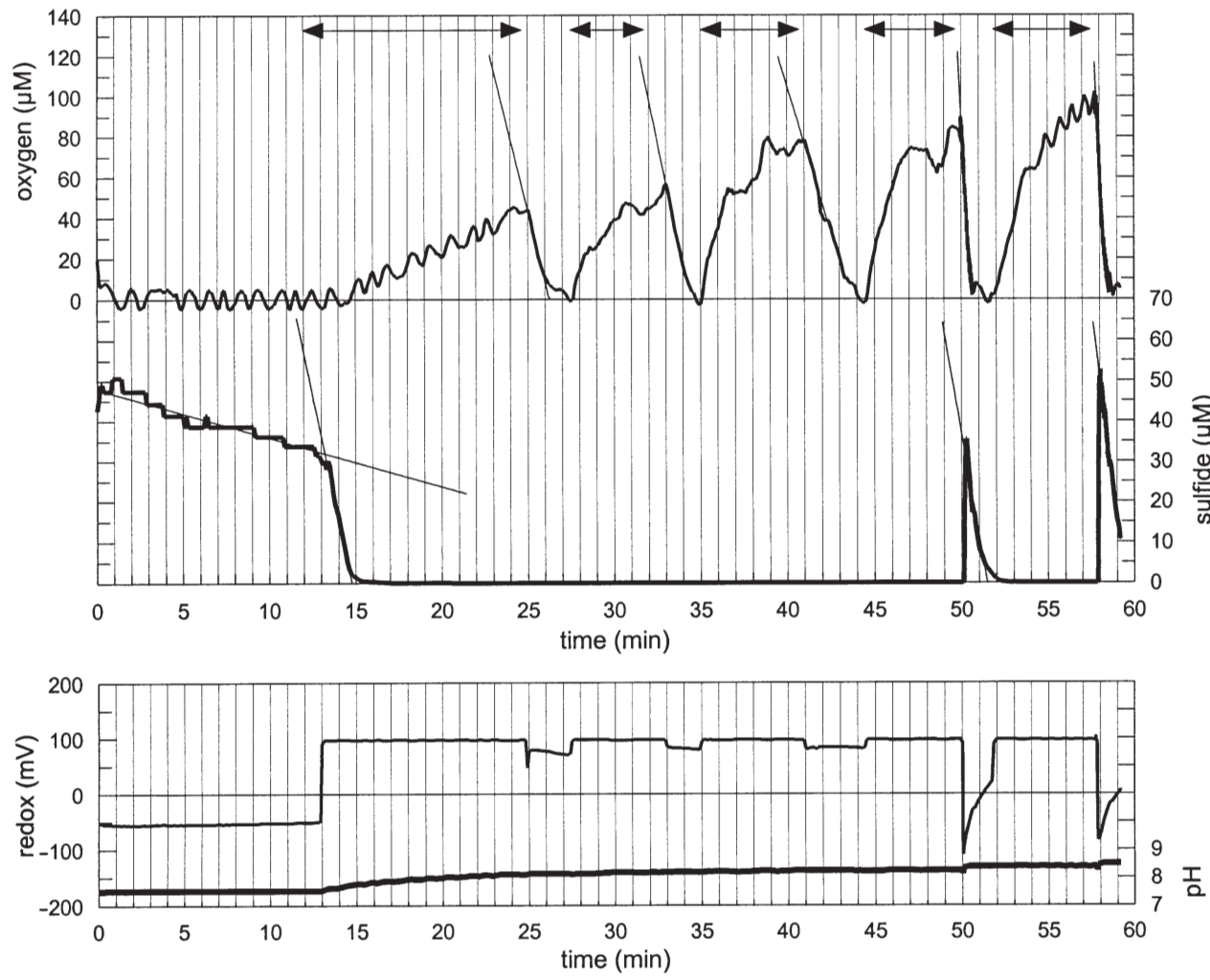

Fig. 2. Time course of oxygen and sulfide (upper panel) and redox and $\mathrm{pH}$ (lower pannel) as observed in a typical BOSM (Biological Oxygen and Sulfide Monitor) experiment using software designed by W. J. Beukema (Electronic Workshop Biol. Dept., University of Groningen, The Netherlands). The sampling time for the 50.0 to 50.6 and the 57.7 to 58.8 min periods was $0.01 \mathrm{~min}$, and for the remaining periods was 0.1 min. The total number of observations for each parameter was 730. Horizontal double-headed arrows indicate periods of aeration during which fluctuations are more pronounced. Sulfide present at the start originated from the lagoon; sulfide additions were made at 50.0 and $57.8 \mathrm{~min}$. Straight lines are based on regression data and the slopes were used to calculate process velocities
In the sediment, the major pools of $\mathrm{P}$ were the Cabound and organic pools (Table 2), which accounted for about 65 and $33 \%$ of sedimentary $P$, respectively. Detrital Ca-bound $\mathrm{PO}_{4}$, which is considered not to be available for organisms (Ruttemberg 1992, Gomez et al. 1999), was, on average, 3 times higher than the more reactive authigenic pool and was more abundant in the deeper layers. In the sediment, concentrations of total $\mathrm{P}, \mathrm{Ca}$-bound $\mathrm{PO}_{4}$ and labile $\mathrm{PO}_{4}$ increased somewhat with depth. In the interstitial water the average $\mathrm{PO}_{4}$ concentration was very high (34 $\mathrm{nmol} \mathrm{cm} \mathrm{cm}^{-3}$ ) compared to the worldwide

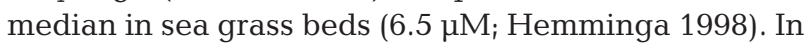
the sediment, total $\mathrm{P}$ concentrations were 3 orders of magnitude higher than in the water column (Table 2).

Table 2. Total phosphorus and P species in (A) water and (B) sediment of the Valle Smarlacca (Valli di Comacchio, Italy) in September 1998. Average of triplicate samples with standard deviation in brackets are given

\begin{tabular}{|c|c|c|c|c|c|c|c|}
\hline \multirow[t]{2}{*}{$\begin{array}{l}\text { (A) Water } \\
\text { cm above } \\
\text { sediment }\end{array}$} & \multicolumn{2}{|c|}{$\begin{array}{c}\text { Total P } \\
\left.(\mathrm{nmol} \mathrm{cm})^{-3}\right)\end{array}$} & \multirow{2}{*}{$\begin{array}{c}\text { Dissolved } \\
\text { phosphate } \\
\left(\mathrm{nmol} \mathrm{cm}^{-3}\right)\end{array}$} & & \multirow{6}{*}{\multicolumn{2}{|c|}{$\begin{array}{c}\text { Ca-bound phosphate } \\
\left(\mathrm{nmol} \mathrm{cm}^{-3}\right)\end{array}$}} & \multirow{7}{*}{$\begin{array}{c}\text { Organic P } \\
\left(\mathrm{nmol} \mathrm{cm}^{-3}\right)^{\mathrm{a}}\end{array}$} \\
\hline & Particulate & Dissolved & & & & & \\
\hline 50 & $2.2(0.8)$ & $1.7(0.7)$ & $<0.1$ & & & & \\
\hline 25 & $2.4(0.6)$ & $1.9(0.7)$ & $<0.1$ & & & & \\
\hline 1 & $4.6(1.4)$ & $0.5(0.4)$ & $<0.1$ & & & & \\
\hline \multirow[t]{2}{*}{$\begin{array}{l}\text { (B) Sediment } \\
\text { Depth layer } \\
(\mathrm{cm})\end{array}$} & \multirow[t]{2}{*}{$\begin{array}{c}\text { Total P } \\
\left(\mathrm{nmol} \mathrm{cm}^{-3}\right)\end{array}$} & \multirow{2}{*}{$\begin{array}{l}\text { Pore water } \\
\text { phosphate } \\
\left(\mathrm{nmol} \mathrm{cm}^{-3}\right)\end{array}$} & \multicolumn{2}{|c|}{$\begin{array}{l}\text { Labile phosphate } \\
\left(\mathrm{nmol} \mathrm{cm} \mathrm{cm}^{-3}\right)\end{array}$} & & & \\
\hline & & & Exchangeable $^{b}$ & Fe-bound & Authigenic & Detrital & \\
\hline $0-2$ & $4763(514)$ & $29(11)$ & $85(50)$ & $17(4)$ & $1030(226)$ & $1591(978)$ & 2011 \\
\hline $2-5$ & 6285 (823) & 54 (19) & $83(27)$ & $18(4)$ & $983(100)$ & $2960(600)$ & 2187 \\
\hline $5-10$ & 8316 (2189) & $24(2)$ & $109(47)$ & $18(5)$ & 1291 (138) & $4823(2453)$ & 2051 \\
\hline
\end{tabular}




\section{Oxygen, sulfide and chl a}

Oxygen and sulfide concentrations, measured in the water column during a diel cycle, are shown in Fig. 3, and in situ profiles of oxygen and sulfide in the sediment representative for afternoon, night and early morning are shown in Fig. 4. High oxygen concentrations, ranging from 200 to $700 \mu \mathrm{M}$, were detected in the water layers 50 and $25 \mathrm{~cm}$ above the sediment (Fig. 3). The concentrations were similar for both layers, confirming that the water column was well mixed. The average phytoplanktonic chl a content of the water column was $105 \mu \mathrm{g} \mathrm{l}^{-1}$. In the $1 \mathrm{~cm}$ water layer overlying the sediment, oxygen concentrations were below the detection limit at all times, whereas the sulfide concentrations were high (average $1.6 \mathrm{mM}$ ); however, no sulfide was found in the remainder of the water column. In the sediment, free sulfide was detected at all times and concentrations were high during the night and early morning (Fig. 4).

The discrepancy in sulfide concentrations in the water layer above the sediment is the result of different methodology: sulfide electrodes (Fig. 4) only detect free sulfide, whereas the method used for the water column measurements (Fig. 3) detects both free sulfide and AVS. The data thus indicate that 80 to $90 \%$ of the sulfide in the water column was present in a bound and acid-volatile form.

On the basis of the sulfide profiles the net rate of sulfide production was calculated (Fig. 5, see legend for details). In the sediment, the 0 to $2 \mathrm{~cm}$ layer was the most active. The activity of the population of sulfate-

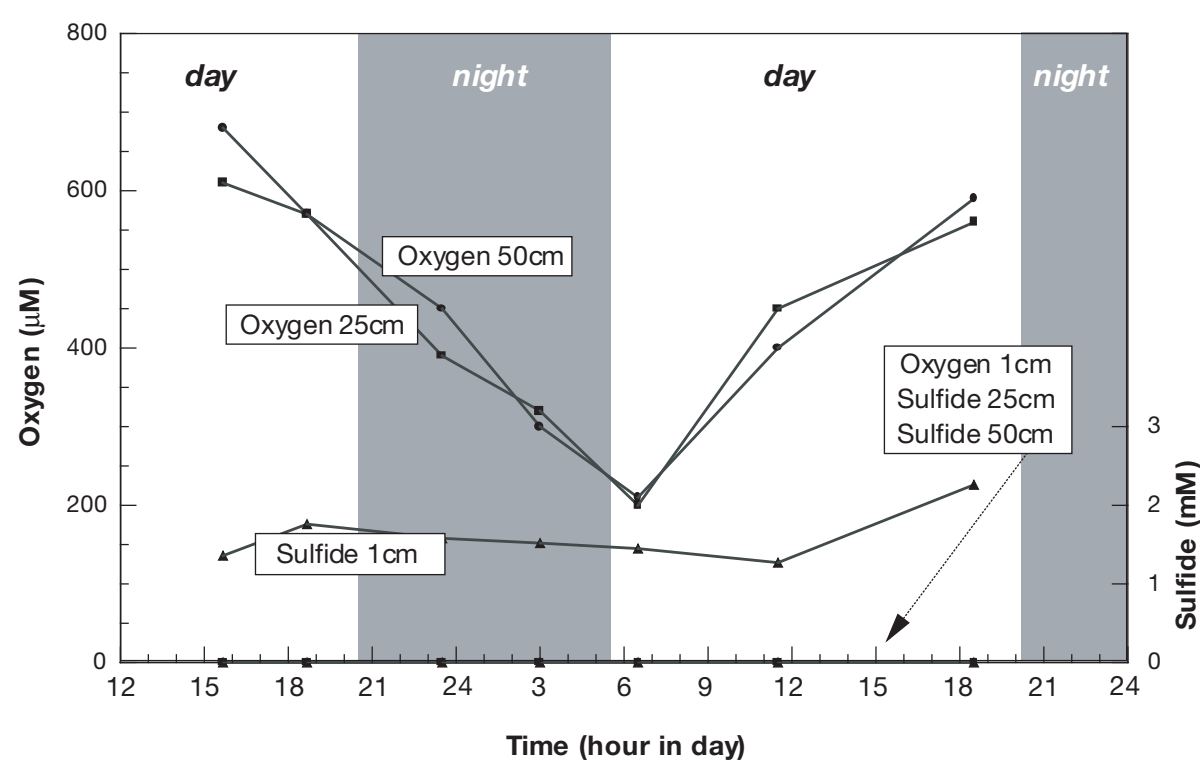

Fig. 3. Dissolved oxygen and total sulfide at 3 depths in the water column of Valle Smarlacca (Italy) over a diel cycle in September 1998

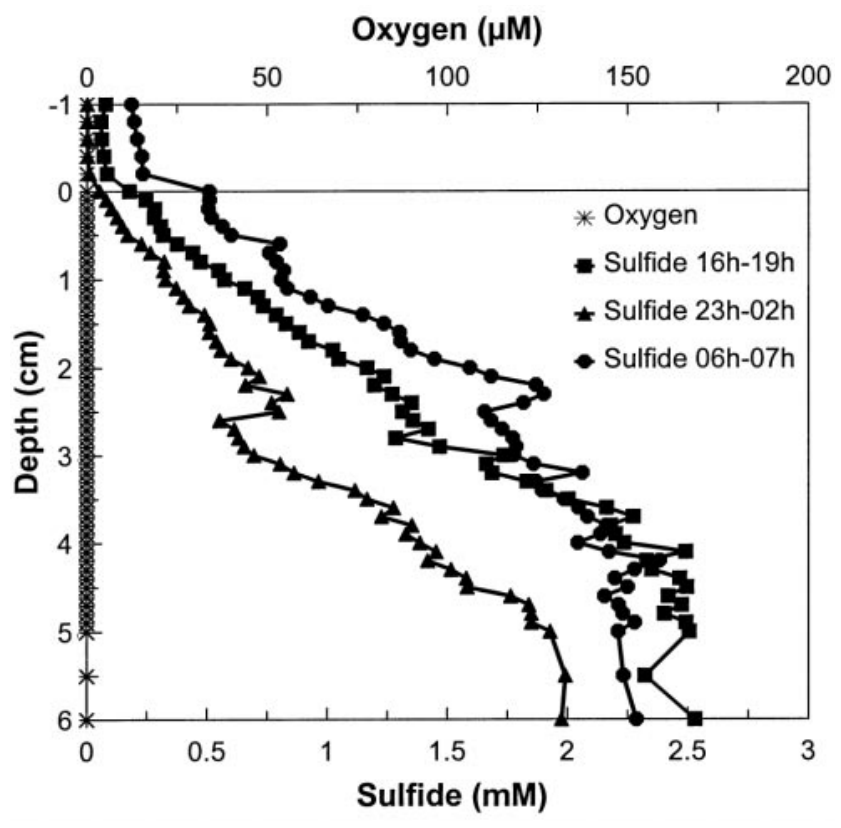

Fig. 4. Vertical profiles of oxygen and free sulfide in the sediment of Valle Smarlacca (Italy), representing 3 periods during a diel cycle in September 1998

reducing bacteria was maximal in the 16 to $19 \mathrm{~h}$ period (rate of sulfide production $8.2 \mathrm{nmol} \mathrm{cm}^{-3} \mathrm{~h}^{-1}$ ), but decreased rapidly to $2.2 \mathrm{nmol}$ sulfide $\mathrm{cm}^{-3} \mathrm{~h}^{-1}$ in the early morning. Lower activities were found in the 2 to $5 \mathrm{~cm}$ sediment layer, and the diel variations were also less pronounced. Virtually no activity was detected in the 5 to $10 \mathrm{~cm}$ sediment layers. In the $1 \mathrm{~cm}$ water layer directly overlying the sediment, the rate of sulfide production and the diel fluctuations were similar to those observed in the 0 to $2 \mathrm{~cm}$ sediment layer.

\section{Chemical buffering capacity and biological activity measurements}

The potential chemical buffering capacity towards free sulfide appeared to be twice as high in the deeper sediment layers compared to the surface layers, whereas the in situ chemical buffering capacity in all layers examined was zero (sulfide present at all times). It appears however, that the chemical buffering capacity was not fully exploited, since stirring of the sediment slurries resulted in the release of compounds that could bind with free 
Table 3. Potential, in situ and released chemical buffering capacity towards free sulfide in the sediment of Valle Smarlacca (Valli di Comacchio, Italy) in September 1998. Average of triplicate samples with standard deviation in brackets are given

\begin{tabular}{|c|c|c|c|}
\hline \multirow[t]{2}{*}{$\begin{array}{l}\text { Depth layer } \\
\text { (cm) }\end{array}$} & \multicolumn{3}{|c|}{$\begin{array}{l}\text { Chemical buffering capacity } \\
\text { ( } \mu \text { mol sulfide } \mathrm{cm}^{-3} \text { sediment) }\end{array}$} \\
\hline & Potential $^{\mathrm{a}}$ & In $s i t u^{\mathrm{b}}$ & $\begin{array}{l}\text { Released } \\
\text { by stirring }\end{array}$ \\
\hline $0-2$ & $15.9(10.2)$ & 0 & 0.61 \\
\hline $2-5$ & $26.8(7.5)$ & 0 & 1.11 \\
\hline $5-10$ & $37.4(6.6)$ & 0 & 2.33 \\
\hline $\begin{array}{l}{ }^{\mathrm{a}} \text { Calculated } \\
{ }^{\mathrm{b}} \text { Deduced fr } \\
{ }^{\mathrm{c}} \text { Calculated } \\
\text { corrected fo }\end{array}$ & $\begin{array}{l}\text { n pools accor } \\
\text { ce of free sul } \\
\text { amount of su } \\
\text { eentration of }\end{array}$ & $\begin{array}{l}\text { Heijs et } \\
\text { ded to sti } \\
\text { recalculat }\end{array}$ & $\begin{array}{l}\text { SM vessels } \\
\mathrm{n}^{3} \text { sediment) }\end{array}$ \\
\hline
\end{tabular}

lected $1 \mathrm{~cm}$ above the sediment surface, low potential rates of chemical and biological sulfide oxidation were found compared to the values found for the sediment. Potential total rates of sulfide oxidation showed a similar pattern.

\section{Dissolved phosphate and iron in sediment slurries}

A significant increase in dissolved $\mathrm{PO}_{4}$ concentrations was observed in sediment slurries in the BOSM set-up amended with sulfide (Fig. 6) and the maximum $\mathrm{PO}_{4}$ release was observed in slurries made from the top layers of

sulfide. The amount released was small compared to the potential chemical buffering capacity and increased somewhat with depth (Table 3).

The net rate of oxygen production in the water column in the daytime was 50 to $70 \mathrm{nmol} \mathrm{cm}{ }^{-3} \mathrm{~h}^{-1}$ (gross production rate: $63 \pm 12 \mathrm{nmol} \mathrm{cm}{ }^{-3} \mathrm{~h}^{-1}$, respiration rate: $2 \pm 4 \mathrm{nmol} \mathrm{cm}^{-3} \mathrm{~h}^{-1}$ ). This high photosynthetic activity is in agreement with the observed chl a concentrations.

Based on the potential chemical oxygen consumption rate, high potential chemical rates of sulfide oxidation were detected in the sediment, with a maximum in the 5 to $10 \mathrm{~cm}$ layer (Table 4). However, potential biological rates were even higher in the layers below $2 \mathrm{~cm}$ depth, indicating that the oxidation of sulfide for the greater part would have been a biological process, provided oxygen was available. In water samples col- the sediment $(0$ to $2 \mathrm{~cm})$. In the steamed slurries intended to be used as abiotic controls, high concentrations of dissolved phosphate were already observed at the start of the experiment and no increase was detected after the addition of sulfide (data not shown). The release of phosphate in the steamed slurries could be due to the hydrolysis of organic P.

Changes in $\mathrm{pH}$ related to the oxidation of sulfide were marginal (Table 5), despite the fact that the molar ratio $\mathrm{HS}^{-} / \mathrm{O}_{2}$ indicated that most of the sulfide added had been oxidized to sulfate. Formation of $\mathrm{S}^{\circ}$ was not observed (data not shown).

The concentration of iron was measured at the start and at the end of the experiments (Table 6). Ferric iron was not present in significant amounts, neither at the start nor at the end of the incubation period.

Table 4. Potential chemical and biological oxygen consumption rates and potential sulfide oxidation rates in the presence of oxygen in water and sediment of Valle Smarlacca (Valli di Comacchio, Italy) in September 1998

\begin{tabular}{|c|c|c|c|c|c|}
\hline \multirow[t]{2}{*}{$\begin{array}{l}\text { Sample, depth } \\
\text { layer }(\mathrm{cm})\end{array}$} & \multicolumn{2}{|c|}{$\begin{array}{l}\text { Potential rate of } \\
\text { oxygen consumption } \\
\left(\mu \mathrm{mol} \mathrm{cm} \mathrm{cm}^{-3} \mathrm{~h}^{-1}\right)\end{array}$} & \multicolumn{3}{|c|}{ 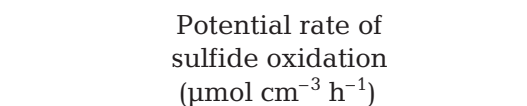 } \\
\hline & Chemical & Biological $^{a}$ & Chemical $^{\mathrm{b}}$ & Biological $^{c}$ & Total $^{\mathrm{d}}$ \\
\hline Water, 1-0 & 0.06 & 0.18 & $0.03-0.12$ & $0.09-0.36$ & 0.08 \\
\hline Sediment, $0-2$ & 5.58 & 15.12 & $2.82-11.16$ & $7.56-30.24$ & 12.36 \\
\hline Sediment, $2-5$ & 13.80 & 40.80 & $6.90-27.60$ & $20.40-81.54$ & 23.76 \\
\hline Sediment, 5-10 & 17.40 & 15.18 & $8.70-34.80$ & $7.62-30.42$ & 4.38 \\
\hline \multicolumn{6}{|c|}{$\begin{array}{l}\text { acalculated as the difference between the total rate of oxygen consumption (data not shown) and the chemical rate of oxyger } \\
\text { consumption }\end{array}$} \\
\hline \multirow{2}{*}{\multicolumn{6}{|c|}{$\begin{array}{l}{ }^{\mathrm{b}} \text { Calculated from the potential chemical oxygen uptake rates; values indicate limits depending on products formed according } \\
\text { to Eqs. (1) \& (2) } \\
{ }^{\mathrm{c} C a l c u l a t e d} \text { from potential biological oxygen uptake rates; values indicate limits depending on products formed according to } \\
\text { Eqs. (1) \& (2) }\end{array}$}} \\
\hline & & & & & \\
\hline \multicolumn{6}{|c|}{$\begin{array}{l}{ }^{\mathrm{d} C a l c u l a t e d} \text { as the difference between the total rate of sulfide removal and the rate observed in steamed controls. Based on } \\
\text { measurements with sulfide electrodes }\end{array}$} \\
\hline
\end{tabular}




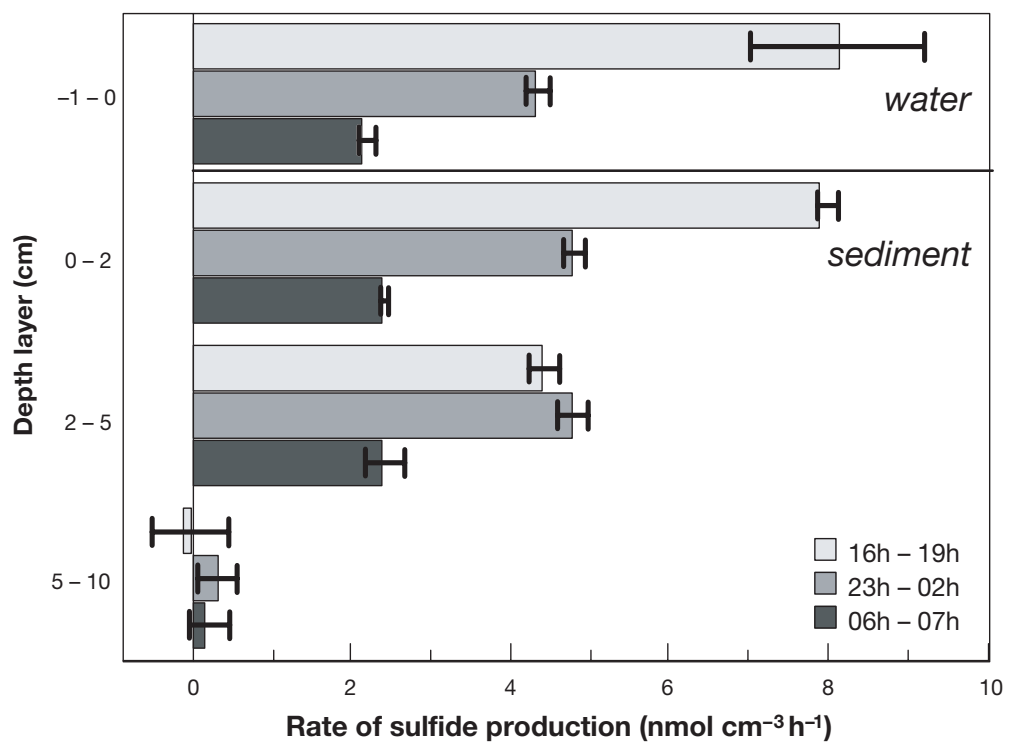

Fig. 5. Average sulfide production rates over a diel cycle in water and sediment of the Valle Smarlacca, September 1998. Rates were calculated for 4 depth layers from hourly sulfide profiles according to Fick's first law, a sediment porosity of 0.8 to 0.9 and a sulfide diffusion coefficient of $0.0333 \mathrm{~cm}^{2} \mathrm{~h}^{-1}$ (Nelson et al. 1986)

\section{DISCUSSION}

Although the Valle Smarlacca is separated from the hypertrophic Valli di Comacchio, it receives high loads of nutrients from the polluted Reno River and from the adjacent ponds used for fish farming. Nevertheless, the dissolved phosphate concentration in the water column was extremely low, which may be taken as an indication that phosphate availability is somehow controlling the biological activities in the ecosystem. If so, any process that contributes to the (partial) abolition of phosphate limitation would result in increased rates of primary production and other biological activities. In this context, the release of phosphate from the sediment due to the presence of sulfide appears to be highly relevant.
Release of phosphate from the sediments due to the presence of free sulfide would also effectuate an increased supply of utilizable substrates for sulfide-producing bacteria. This positive feedback mechanism would only be halted when other factors, such as the intensity of photosynthetically active irradiation, became limiting or when free sulfide concentrations reached lethal concentrations for primary producers. Since the latter organisms are the driving force of the processes described above, the ecosystem would soon develop into a sapropelium and recuperation would only be feasible after sulfide production had ceased and any sulfide present had been removed. However, the restored environmental conditions allowing the (re-)colonization by oxygenic phototrophs would soon end due to the fact that under the re-established oxic conditions phosphate would precipitate again. This could initiate a new cycle of events. Thus, a one-time observation showing a relatively healthy system does not imply that this is a long-lasting phenomenon. Appearances could easily be deceptive in this respect.

In the Valle Smarlacca a strong build-up of sulfide was observed (Figs. $3 \& 4$ ) and the 0 to $2 \mathrm{~cm}$ sediment layer and the water layer directly above were found to be the main sites of sulfide production (Fig. 5). It is anticipated that a large part of the decaying organic matter was produced in the water column; in earlier reports it was postulated that sulfide production takes place in the slime settled on the sediment (Giordani et al. 1997). In Ruppia-dominated ecosystems it was observed that sulfide production in the water column was related to epiphyte coverage and that AVS in the sediment doubled compared to spots with healthy plants, presumably due to settling of the epiphyte slime (Viaroli et al. 1997). The accumulation of sulfide is not only determined by the rate of production, but also by the chemical and biological rate of sulfide

Table 5. Sulfide oxidation, pH, and molar ratio sulfide/oxygen in water and sediment slurries of Valle Smarlacca (Valli di Comacchio, Italy)

\begin{tabular}{|c|c|c|c|c|c|}
\hline \multirow[t]{2}{*}{$\begin{array}{l}\text { Sample, depth } \\
\text { layer }(\mathrm{cm})\end{array}$} & \multirow{2}{*}{$\begin{array}{l}\% \text { sample } \\
\text { in BOSM } \\
\text { slurry }(v / v)\end{array}$} & \multicolumn{2}{|c|}{$\begin{array}{c}\text { Sulfide } \\
\text { (nmol cm } \mathrm{cm}^{-3} \text { slurry) }\end{array}$} & \multirow{2}{*}{$\begin{array}{c}\Delta \mathrm{pH} \\
\text { after sulfide } \\
\text { oxidation }^{\mathrm{a}}\end{array}$} & \multirow[t]{2}{*}{$\begin{array}{l}\text { Molar ratio } \\
\mathrm{HS}^{-} / \mathrm{O}_{2}{ }^{\mathrm{b}}\end{array}$} \\
\hline & & Added & Final & & \\
\hline Water, 1-0 & 100 & 250 & 0 & -0.01 & 0.46 \\
\hline Sediment, 0-2 & 15 & 250 & 0 & $+0.05(0.02-0.07)$ & 0.82 \\
\hline Sediment, 2-5 & 11 & 250 & 0 & $+0.04(0.02-0.05)$ & 0.58 \\
\hline Sediment, 5-10 & 20 & 250 & 0 & $+0.05(-0.03-0.07)$ & 0.28 \\
\hline
\end{tabular}


Table 6. Ferrous and ferric iron concentrations at start and end of the incubation period in the BOSM set-up. Averages of triplicate measurements; standard deviation in brackets

\begin{tabular}{|c|c|c|c|c|c|c|}
\hline \multirow[t]{2}{*}{$\begin{array}{l}\text { Sediment layer } \\
(\mathrm{cm})\end{array}$} & \multicolumn{2}{|c|}{$\begin{array}{c}\text { Ferrous iron } \\
\left(\mu \mathrm{mol} \mathrm{ml} \mathrm{l}^{-1} \text { slurry }\right)\end{array}$} & \multicolumn{2}{|c|}{$\begin{array}{l}\text { Ferrous iron plus ferric iron } \\
\qquad\left(\mu \mathrm{mol} \mathrm{ml} \mathrm{m}^{-1} \text { slurry }\right)\end{array}$} & \multicolumn{2}{|c|}{ 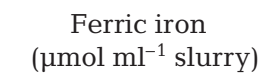 } \\
\hline & Start & End & Start & End & Start & End \\
\hline $0-2$ & $0.245(0.038)$ & $0.303(0.030)$ & $0.257(0.037)$ & $0.297(0.016)$ & 0.011 & -0.006 \\
\hline $2-5$ & $0.391(0.012)$ & $0.454(0.012)$ & $0.378(0.032)$ & $0.455(0.009)$ & -0.013 & 0.001 \\
\hline $5-10$ & $1.246(0.029)$ & $2.492(0.043)$ & $1.245(0.038)$ & $2.429(0.040)$ & -0.001 & -0.063 \\
\hline
\end{tabular}

removal. Previously, the latter were called the chemical and biological sulfide buffering capacity of an ecosystem (Heijs et al. 1999) and it was shown that the chemical buffering capacity largely depends on labile ferric iron and ferrous iron fractions, while the biological buffering capacity is mainly due to the activities of colorless sulfur bacteria (Schaub \& Van Gemerden 1996, Heijs et al. 1999).

The sediment of Valle Smarlacca contained high concentrations of iron (Table 1), of which the major part $(72$ to $77 \%$ ) was in the ferrous form. Total iron concentrations increased with depth and the form changed from predominantly labile iron in the upper sediment layers ( $52 \%$ of total iron) to crystalline iron in the deeper sediment ( $65 \%$ of total iron).

The content of labile iron and the fact that only about half of the labile ferrous iron in the 0 to $2 \mathrm{~cm}$ sediment layer was present as FeS suggest that the ecosystem has a large chemical buffering capacity towards sulfide (Table 1). However, the in situ buffering capacity, judged from the presence of free sulfide, was exhausted, whereas stirring of the sediment slurries resulted in the release of a small fraction of the potential chemical pool. This indicates that part of the iron

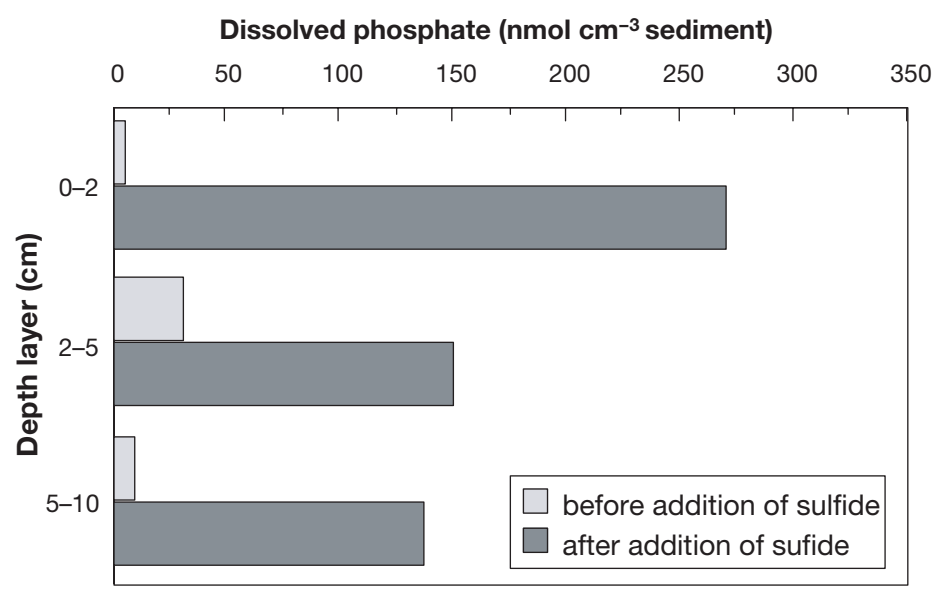

Fig. 6. Phosphate concentrations before and after the addition of sulfide to sediment slurries from Valle Smarlacca incubated in the BOSM set-up was present in a less reactive form (Canfield et al. 1992, Giordani et al. 1997) and did not take part in the buffering towards sulfide. Similar phenomena can be expected to take place when the sediment of these shallow lagoons is suspended during storms.

The potential biological rate of sulfide oxidation of the sediment was high, in particular in the 2 to $5 \mathrm{~cm}$ layer (Table 4), which coincided with the most probable number counts on colorless sulfur bacteria (data not shown). However, the majority of colorless sulfur bacteria require oxygen for the oxidation of sulfide and, as shown in Fig. 3, this was absent. In addition, the concentrations of nitrate, used by some species instead of oxygen, were below the detection limit. Comparison of the potential biological rates of sulfide oxidation with the potential total rate of sulfide oxidation (Table 4) indicates that all sulfide added was completely oxidized to sulfate.

Zero chemical buffering capacity was encountered in September 1998. In addition, the powerful potential biological sulfide oxidizing capacity could not be exploited due to lack of oxygen. As a consequence, the concentration of free sulfide increased to reach high levels.

Sediments of shallow lagoons can be supplied with oxygen by 2 mechanisms: (1) the diffusive transport of oxygen from the water phase to the sediment layers, and (2) the process known as radial oxygen loss (ROL) of plant roots. The prevailing concentration of oxygen in the oxic part of the water column was the net result of the rates of oxygen production and respiration by phytoplankton, Ruppia and epiphytes, aerobic respiration by heterotrophic microbes, presumably also sulfide oxidation by colorless sulfur bacteria, and the transport of oxygen into the sediment. However, no oxygen was detected in the water layer directly overlying the sediment; in addition, this layer contained sulfide at all times (Fig. 3), and thus in situ oxygen transport from the water column into the sediment can be excluded. Oxygen for the oxidation of sulfide (by abiotic reactions or by colorless sulfur bacteria) will have been used at the oxic/sulfidic interface, which was situated at least $1 \mathrm{~cm}$ above the sediment surface. 
In addition, the second mechanism by which sediments can be enriched with oxygen (ROL) was of minor importance. Incubation experiments with Ruppia, with leaves cleaned of epiphytes, at saturating light conditions $\left(600 \mu \mathrm{E} \mathrm{m} \mathrm{m}^{-2} \mathrm{~h}^{-1}\right)$ showed very low net production of oxygen (data not shown), i.e. the plants were photosynthetically not very active. This indicates that the input of oxygen into the sediment by ROL must have been marginal and certainly insufficient to oxidize the sulfide produced. Thus, roots of Ruppia were exposed to free sulfide for prolonged periods of time, presumably resulting in root, rhizome and shoot damage and a lowering of the survival of the plants.

The net oxygen production rate calculated from the in situ concentrations of oxygen (Fig. 3) was somewhat lower $\left(36 \mathrm{nmol} \mathrm{cm} \mathrm{cm}^{-3} \mathrm{~h}^{-1}\right.$ ) than that calculated from the bottle incubations, which is easily explained by the fact that we are not dealing with a closed system. During the night, oxygen production in the water column will have been negligible and the decrease would thus reflect the oxygen consumption due to respiration. The respiration rate in dark bottles was only $2 \mathrm{nmol} \mathrm{cm}^{-3}$ $\mathrm{h}^{-1}$, whereas the decrease in the Valle Smarlacca was $33 \mathrm{nmol} \mathrm{cm}{ }^{-3} \mathrm{~h}^{-1}$ (calculated from Fig. 3). However, 2 processes were excluded from the bottle experiment: (1) the respiration by Ruppia and epiphytes, and (2) the aerobic sulfide oxidation by colorless sulfur bacteria.

The concentrations of total $\mathrm{P}, \mathrm{Ca}$-bound $\mathrm{PO}_{4}$ and labile $\mathrm{PO}_{4}$ in the sediment of Valle Smarlacca are comparable to previously reported data on phosphorus speciation in eutrophic marine sediments (Weng et al. 1994, Giordani et al. 1996, Sorokin et al. 1996a, Silva \& Sampaio 1998). As shown in Table 2 the major part of the total phosphorus in the sediment was present as Ca-bound $\mathrm{PO}_{4}$ (55 to $74 \%$ ), the labile $\mathrm{PO}_{4}$ pool only contributed 2 to $3 \%$, whereas Fe-bound $\mathrm{PO}_{4}$ was less than $1 \%$. No phosphate was detected in the water column (Table 1). Compared to this, the sediment harbors an extremely large amount of phosphorus.

In slurry experiments (BOSM set-up), the presence of free sulfide induced a significant release of dissolved $\mathrm{PO}_{4}$ (Fig. 6). It is generally assumed that sulfide releases phosphate from the Fe-bound pool only (Moore \& Reddy 1994, Giordani et al. 1996, Stal et al. 1996, Roden \& Edmonds 1997). The extraction method used to assay Fe-bound phosphate $(0.1 \mathrm{M} \mathrm{NaOH})$ is not as effective as other methods; however, taking into account that $\mathrm{Fe}$-bound $\mathrm{PO}_{4}$ was only present at concentrations ranging from 13 to $23 \mathrm{nmol} \mathrm{cm}^{-3}$, the more than 10-fold higher phosphate release observed in sediment slurries suggests that phosphate from the organic and/or the Ca-bound $\mathrm{PO}_{4}$ pool was also released.

From the Ca-bound $\mathrm{PO}_{4}$ pool the detrital part is minimally reactive under environmental conditions (Rut- temberg 1992), but dissolution of the authigenic pool has been reported to occur when the $\mathrm{pH}$ was lowered from 8 to 7, provided oxygen was present (Gomez et al. 1999). If the oxidation of sulfide, once oxic conditions are restored in autumn and winter, resulted in a slight acidification of the sediment, then authigenic $\mathrm{Ca}$ bound $\mathrm{PO}_{4}$ in the surficial layers of the sediment could resolve. This could result in intense blooms of epiphytes and macroalgae as observed in the summer. However, after sulfide depletion in sediment slurries, invariably a small increase in $\mathrm{pH}$ was observed, despite the fact that the molar ratio $\mathrm{HS}^{-} / \mathrm{O}_{2}$ indicated that most, if not all, of the sulfide had been oxidized to sulfate (Table 5). In addition, acidification by oxidation of ferrous iron with $\mathrm{O}_{2}$, resulting in extensive proton donation, must have been a marginal process since net formation of ferric iron was not observed. Likewise, $\mathrm{S}^{\circ}$ formation, indicating the reduction of ferric iron by sulfide, was not observed. Instead, the net formation of ferrous iron (Table 6) suggests that reductive processes were dominant. It thus appears highly unlikely that acidification is the explanation for the 'sulfide effect', so the responsible mechanism has not been elucidated yet.

From these observations it can be concluded that sulfide might play an even more important role in the release of phosphate from the sediment than previously assumed. In eutrophic coastal lagoons this process acts as a positive feedback on eutrophication, resulting in increased sulfide production in the sediment. As oxygen becomes the limiting factor the sulfide cannot be removed and toxic concentrations are reached, finally resulting in the disappearance of rooted phanerogams such as Ruppia.

Acknowledgements. We thank Mr Giovanni Salami and the personnel of the Valle Smarlacca fish farm for the possibility to work in Valle Smarlacca, the excellent research facilities provided and their hospitality and help during the field campaign. This study is a contribution to the European Union ELOISE thematic network (ELOISE No. 171) in the framework of the ROBUST project- 'ROle of BUffering capacities in STabilising coastal lagoon ecosystems' - which is carried out under contract ENV4-CT96-0218. This is publication 2695 of the Centre of Estuarine and Coastal Ecology.

\section{LITERATURE CITED}

Andreoli C, Moro I, Tognetto L (1998) Il fitoplancton delle Valli diComacchio da gennaio a dicembre 1997. Laguna 5:16-23

APHA (1975) Standard methods for the examination of water and waste-waters, 14th edn. American Public Health Association, Washington, DC

Aspila KI, Agemian H, Chau ASY (1976) A semiautomated method for the determination of inorganic, organic and total phosphate in sediments. Analyst 101:187-197 
Barbanti A, Bergamini MC, Frascari F, Miserocchi S, Rosso G (1994) Critical aspects of sedimentary phosphorus fractionation. J Environ Qual 23:1093-1102

Boström B, Andersen JM, Fleischer S, Jansson M (1988) Exchange of phosphorus across the sediment-water interface. Hydrobiologia 170:229-244

Caffrey JM, Kemp WM (1991) Seasonal and spatial patterns of oxygen production, respiration and root-rhizome release in Potamogeton perfoliatus L. and Zostera marina L. Aquat Bot 40:109-128

Canfield DE (1989) Reactive iron in marine sediments. Geochim Cosmochim Acta 53:619-632

Canfield DE, Raiswell R, Botrell S (1992) The reactivity of sedimentary iron minerals towards sulfide. Am J Sci 292: 659-583

Cline JD (1969) Spectrophotometric determination of hydrogen sulfide in natural waters. Limnol Oceanogr 14: 454-459

Dallocchio F, Ghion F, Milan C, Viaroli P (1998) Variazoni temporali delle caratteristiche chimico-fisiche delle acque delle Valli di Comacchio. Laguna 5:4-15

Giordani G, Bartoli M, Cattadori M, Viaroli P (1996) Sulphide release from anoxic sediments in relation to iron availability and organic matter recalcitrance and its effect on inorganic phosphorus recycling. Hydrobiologia 329:211-222

Giordani G, Azzoni R, Bartoli M, Viaroli P (1997) Seasonal variations of sulphate reduction rates, sulphur pools and iron availability in the sediment of a dystrophic lagoon (Sacco di Goro, Italy). Wat Air Soil Pollut 99:363-371

Golterman HL (1995) The role of the iron hydroxide-phosphate-sulfide system in phosphate exchange between sediments and the overlying water. Hydrobiologia 297: $43-45$

Golterman HL (1997) The distribution over iron-bound and calcium-bound phosphate in stratified sediments. Hydrobiologia 364:75-81

Gomez E, Durillion C, Rofes G, Picot B (1999) Phosphate adsorption and release from sediments of brackish lagoons: $\mathrm{pH}, \mathrm{O}_{2}$ and loading influence. Wat Res 33: $2437-2447$

Heijs SK, Jonkers HM, Van Gemerden H, Schaub BEM, Stal LJ (1999) The buffering capacity towards free sulfide in sediments of a coastal lagoon (Bassin d'Arcachon, France): the relative importance of chemical and biological processes. Estuar Coast Shelf Sci 49:21-35

Hemminga MA (1998) The root/rhizome system of sea grasses: an asset and a burden. J Sea Res 39:183-196

Hieltjes AHM, Lijklema L (1980) Fractionation of inorganic phosphates in calcareous sediments. J Environ Qual 9: 405-407

Jørgensen BB (1982) Mineralization of organic matter in the sea bed-the role of sulphate reduction. Nature 296: 643-645

Lovley DR, Phillips EJP (1987) Rapid assay for reducible ferric iron in aquatic sediments. Appl Environ Microbiol 53: 1536-1540

Editorial responsibility: Gary King,

Walpole, Maine, USA
Moore PA Jr, Reddy KR (1994) Role of Eh and pH on phosphorous geochemistry in sediments of Lake Okeechobee, Florida. J Environ Qual 23:955-964

Murphy J, Riley JP (1962) A modified single solution method for the determination of phosphate in natural waters. Ann Chim Acta 27:31-36

Nelson DC, Jørgensen BB, Revsbech NP (1986) Growth pattern and yield of a chemoautotrophic Beggiatoa sp. in oxygen-sulfide microgradients. Appl Environ Microbiol 52: 225-233

Pedersen O, Borum J, Duarte CM, Fortes MD (1998) Oxygen dynamics in the rhizosphere of Cymodecea rotundata. Mar Ecol Prog Ser 169:283-288

Piccoli F (1998) Passato e presente della vegetazione delle Valli di Comacchio. Laguna 5/98:24-27

Reeburgh WS (1967) An improved interstitial water sampler. Limnol Oceanogr 12:163-165

Roden EE, Edmonds JW (1997) Phosphate mobilization in iron-rich anaerobic sediments: microbial Fe(III) oxide reduction versus iron-sulfide formation. Arch Hydrobiol 139:347-378

Ruttemberg KC (1992) Development of a sequential extraction method for different forms of phosphorus in marine sediment. Limnol Oceanogr 37:1460-1482

Schaub BEM, Van Gemerden H (1996) Sulfur bacteria in sediments of two coastal ecosystems: the Bassin d'Arcachon and the Etang du Prévost, France. Hydrobiologia 329: $199-210$

Silva CAR, Sampaio LS (1998) Speciation of phosphorus in a tidal floodplane forest in the Amazone estuary. Mangroves Salt Marshes 2:51-57

Smolders A, Roelofs JGM (1993) Sulphate-mediated iron limitation and eutrophication in aquatic ecosystems. Aquat Bot 46:247-253

Sorokin YI, Dallocchio F, Gelli F, Pregnolato L (1996a) Phosphorous metabolism in anthropogenically transformed lagoon ecosystems: The Comacchio lagoons (Ferrara, Italy). J Sea Res 35:243-250

Sorokin YI, Sorokin PY, Gnes A (1996b) Structure and functioning of the anthropogenically transformed Comacchio lagoonal ecosystem (Ferrara, Italy). Mar Ecol Prog Ser 133: $57-71$

Stal LJ, Behrens SB, Villbrandt M, Van Bergeijk S, Kruining F (1996) The biogeochemistry of two eutrophic marine lagoons and its effect on microphytobenthic communities. Hydrobiologia 329:185-198

Valderrama JC (1981) The simultaneous analysis of total nitrogen and total phosphorus in natural waters. Mar Chem 10:109-122

Viaroli P, Bartoli M, Fumagalli I, Giordani G (1997) Relationship between benthic fluxes and macrophyte cover in a shallow brackish lagoon. Wat Air Soil Pollut 99:533-540

Weng H, Presley BJ, Armstrong D (1994) Distribution of sedimentary phosphorous in Gulf of Mexico estuaries. Mar Environ Res 37:375-392

Submitted: December 13, 1999; Accepted: September 2, 2000 Proofs received from author(s): October 26, 2000 